\title{
Contending Geo-logics: Energy Security, Resource Ontologies, and the Politics of Expert Knowledge in Estonia
}

\author{
Dr Kärg Kama \\ *Pre-print version. Final article is published in Geopolitics \\ http://dx.doi.org/10.1080/14650045.2016.1210129
}

\begin{abstract}
Engaging with nascent scholarly efforts to foreground the 'geo' of geopolitics, this article examines how certain low-quality geological substances are constituted as strategic, 'unconventional' fossil fuel resources, the exploitation of which is deemed indispensable for energy security reasons. Based on a detailed study of oil shale exploitation in Estonia, the paper specifically analyses the politics of knowledge that enable such carbon-intensive and energy-inefficient industries to perpetuate at the national level and, moreover, subvert the neoliberal imperatives of energy sector deregulation and decarbonisation arising from EU policies. This analysis leads to two key arguments. At one level, the Estonian case evidences and contextualises the growing recognition that 'energy security' represents a multifaceted and dynamic construct as it highlights, in particular, the contingency of expert knowledge in its conceptualisation and performance. What counts as energy security is in this case articulated via shifting and contested modes of knowledge-making, whereby state- and market-led modes of energy governance are continuously renegotiated. At another level, however, the politics of knowledge is explained here as exercised through contending ontologies of the fossil fuel resource that pivots security claims, or 'geo-logics', which has multiplying effects on resource materiality.
\end{abstract}

Keywords: materialist geopolitics, resource materialities, energy security, expertise, unconventional fossil fuels.

\section{Introduction}

By the year 2016, the energy economy of Estonia was expected to arrive at a definite turning point. Based almost entirely on the exploitation of oil shale, a little known low-quality fossil fuel resource, the state's electricity sector was about to reach the end of the transitional period stipulated by its admission to the EU market economy. As for other Central European and Baltic (CEB) states whose accession process coincided with the building of a single European market for electricity and gas, 'energy transition' had come to be equated with the restructuring of former state monopolies under neoliberal principles of free market competition and consumer choice. ${ }^{1}$ To amplify the need for extensive reforms, this occurred at a time when the EU assumed global leadership in moving towards a substantially lower carbon economy by cutting at least 80 per cent of all emissions, as outlined in the 'Energy 2050' roadmap (40 per cent by 2030).2 Estonia, like other CEB countries, was thus required to both deregulate and decarbonise its energy sector despite having initially been assigned generous Kyoto targets. For local experts, these combined demands were unequivocally seen to undermine the prospects of maintaining a self-sufficient fossil fuel industry or to even bring oil shale extraction to a halt. While Estonia currently represents the least energy import-dependent member state, it was feared that it would become heavily reliant on external supplies, most likely from neighbouring Russia, following the requirement to close down the highly polluting Soviet-era power 
generation plants developed for oil shale combustion. ${ }^{3}$ Even if some generation capacity could be maintained, the industry's competitiveness in the open market was predicted to be ruled out by concurrent amendments in carbon emissions trading. ${ }^{4}$

Yet to date, none of this has happened. Instead, oil shale exploitation is firmly on the rise, having safeguarded its position amidst ongoing negotiations over the EU energy and climate frameworks. Over recent years, this policy process has come to be dominated by member states' assertions of their 'energy security' concerns and sovereign rights to decide over the structure of supply, as assured in the Treaty of Lisbon. ${ }^{5}$ Their discretion to utilise locally available lower grade, carbon-potent fossil fuel resources, including brown coal and shale gas, has thereby turned into one of the key issues that inform the design of the internal energy market. In recent EU policy documents, these 'unconventional fuels', which were hitherto considered either obsolete or incompatible with a lower carbon economy, have been reappraised as matching the overall drive towards European energy and resource security in light of growing import dependence and frequent disruptions to supply. Indeed, the exploitation of unconventionals is increasingly invoked as a geo-economically and -politically sensible response to alleged threats from third countries that have not fully subscribed to the market agenda, especially concerning the readily available, yet politically charged, imports from Russia and other CIS countries. The EU Energy Security Strategy 2014, in particular, lists 'sustainable production of fossil fuels' among its main options for supply diversification and calls for extensive research on unconventional sources. ${ }^{6}$ Given the major stakes associated with shale gas exploration in Poland, the UK, and other countries, there are now heated debates over the need for EU-wide regulation of unconventional energy development. This remains in tension with states' claims to sovereignty in their policy choices, giving due recognition to the principle of subsidiarity. ${ }^{7}$

Focussing on the case of oil shale, this article interrogates the national politics of knowledge that enable such carbon- and energy-intensive forms of extraction to perpetuate under the pretext of energy security and geopolitical interests. In broad terms, the unrealised fate of the Estonian industry affirms recent observations in critical geographical studies that the pursuit of energy transition amounts to a highly contextual and contested process, as the linear imperatives of energy sector deregulation and decarbonisation need to be renegotiated every time when introduced into new locations. ${ }^{8}$ Departing from this approach, I propose to examine the dynamics of energy transitions by way of foregrounding the fossil fuel resource that pivots conflicting accounts of state-market relations in energy provision and appropriate means of supply. Instead of taking the presence of oil shale as the object of disagreement for granted, I argue that we need to examine more closely what has made certain components of the geophysical world to become regarded as a resource in the first place and, further, how resources may be conceived differently and themselves transformed as a result of changing social conventions on their nature, utility and importance. More precisely, my focus is on the amalgam of historical perceptions, scientific calculations, economic arrangements and technical infrastructures that place some energy-potent substances at the heart of geopolitical considerations while excluding others, or to consider what Richardson and Weszkalnys succinctly term 'resource ontologies'. ${ }^{9}$ 
Combining recent critical analyses of resource and energy security ${ }^{10}$ with nascent 'object-oriented' and 'materialist' approaches to critical geopolitics ${ }^{11}$, I specifically account for the 'geo' of energy geopolitics as constituted by the contending logics and practices through which strategic energy resources are continuously (re)made. ${ }^{12}$ This opens up two, intersecting arguments.

At one level, the Estonian case substantiates and contextualises the growing recognition that the concept of 'energy security' cannot be readily defined, but stands for a multifaceted, dynamic and highly contested state of affairs. ${ }^{13}$ Even though the term is broadly taken to denote a "reliable and adequate supply of energy at reasonable prices",14 it is difficult to find an exhaustive list of criteria as to how exactly, for whom, and from what sources and at what costs energy should be made available. Instead of measuring up to a series of given attributes, the definition may encompass a myriad of articulations depending on who assumes the specialist knowledge and the political authority to determine what is reliable, adequate and reasonable. By focusing on the formation of such knowledge politics, my study concurs with Bridge in observing that energy security assertions have socially normalising and reproductive effects; a performative dimension that is particularly salient in CEB energy reforms. ${ }^{15}$ But I want to emphasise further the contingency of expert knowledge in this process. At a time when new member states have contributed an overall concern with security to EU policy-making, ${ }^{16}$ the Estonian study reveals that there is in fact little consensus among national authorities. Instead, energy security has proven to be an inherently contentious and shifting problem in the face of competing claims to expertise. Even more intriguingly, this has destabilised the status of the fossil fuel industry, hitherto deemed indispensable for ensuring security. As local actors are beginning to renounce established conventions and forge various, if incompatible, supply scenarios, the fetishised geopolitical notion of 'strategic resources' - that is "how they are understood and granted agency to explain power relations" 17 - gives way to new conceptualisations.

At another level, this leads me to interrogate energy geopolitics as comprising various attempts to define and enact certain material composites as energy resources, or what can be called the 'ontological politics' of resource-making. ${ }^{18} \mathrm{My}$ emphasis on resource ontologies here adjoins emerging efforts to augment the notion of geopolitics with an account of the diverse political agencies and epistemic communities that underpin Earth governance, or 'geo-politics'. ${ }^{19}$ In particular, this approach resonates with recent calls for 'vertical' or 'volumetric' readings that direct analytical lens from territorial disputes over national borders to the depths of the underground, thus evading the tendency to reduce fossil fuel resources to a central, yet in essence a tacit and inert backdrop of interstate power struggles. ${ }^{20}$ Rather, the 'geo' is recognised here as both constituted and itself acquiring differential capacities through continuous struggles over determining the status, qualities and viability of the given resource. The observed tensions between 'contending geo-logics', as indicated in the title, are therefore limited to neither geoscientific disputes nor state politics, but denote more broadly the rival modes of knowledge-making through which various resource definitions are explored, with multiplying effects on both the political and the geophysical. Moreover, the Estonian case reveals that such ontological politics of resourcemaking may span different time horizons, since protagonists disagree not just over 
the significance and essence of oil shale, but also what it meant in the past and what it might become in the future.

Having positioned itself as 'fundamentally insecure' owing to its borderland location, Estonia is subject to extensive studies of postsocialist discourses in critical geopolitics. ${ }^{21}$ Yet, the scholarship seldom interrogates the controversies that arise from the state's shale-based electricity system and its role in mediating the EU and CIS energy regimes, especially with regard to the ongoing reconfiguration of the Pan-European 'geo-energy space'. ${ }^{22}$ The following analysis offers a detailed empirical study of how the 'geo' is constituted and staged. It is primarily informed by key informant interviews with forty-two leading industry experts and policy-makers, which were conducted in Tallinn and Brussels in 20102011, along with participant observation at relevant policy events and several visits to oil shale production sites near the Estonia-Russia border. This research witnessed the intense disputes and various national and international efforts that preceded market liberalisation, including a failed attempt to privatise the state energy monopoly and the latter's growing ambitions to sell its products and technological expertise abroad, as described below. Additionally, I traced the restructuring of the industry through a series of informal conversations and ethnographic observations that took place during three consecutive international oil shale conferences in the USA and Jordan in 2010-2012, which included field trips to the newly-acquired Estonian concessions. ${ }^{23}$ The insights from interviews and conference ethnographies were further supplemented by continuous study of historical analyses, EU and national policy documents and media reports published on the industry until 2014.

The analysis begins by explaining oil shale's persistent importance to national energy security ideologies with its status as a 'patrimony', which subverts the imperatives of market liberalisation and integration, yet itself conceals a series of paradoxes. The next two sections document the renegotiation of state- and marketled modes of energy governance in relation to the industry's unique material features and purported needs. I suggest that despite being seriously delayed, or even failed, the marketisation process has contributed to fundamental changes in the setup of national expert knowledge that informs the performance of energy security. Furthermore, I argue that the ongoing reconfiguration of expertise evidences not just shifting registers of security, but also contending ontologies of the matter of security, which lead to multiple enactments of the geological resource as such.

\section{Making an energy resource: patrimony and security}

The historical significance of oil shale extraction to Estonia's economy cannot be understated. Having accounted for approximately 90 per cent of electricity production and 60-75 per cent of primary energy supply (TPES) to date (Figures 1 and 2), the sole indigenous fossil fuel is central to the state's economic competitiveness, its social stability, and its ideologies of national sovereignty. As a major feedstock for thermal power stations and a key raw material for the chemical industry, the organic-rich sedimentary rock continues to provide the population with remarkably low electricity prices, industry with lucrative revenues, and the government with decent dividends which incidentally helped to compensate for budget deficiencies prior to the country's accession to the 
Eurozone. Moreover, following the closure of the Ignalina nuclear power plant in Lithuania in 2010 and subsequent deficiency in the Baltic market, Estonia has turned into a net exporter of electricity, currently selling over half of its total output. ${ }^{24}$ Although the statistical importance of oil shale in electricity generation has dropped slightly as a result of expanding use of renewables, extraction has in fact increased due to growing exports of both shale-based electrical power and shale oil products, with the latter now accounting for a third of the mined ore. ${ }^{25}$

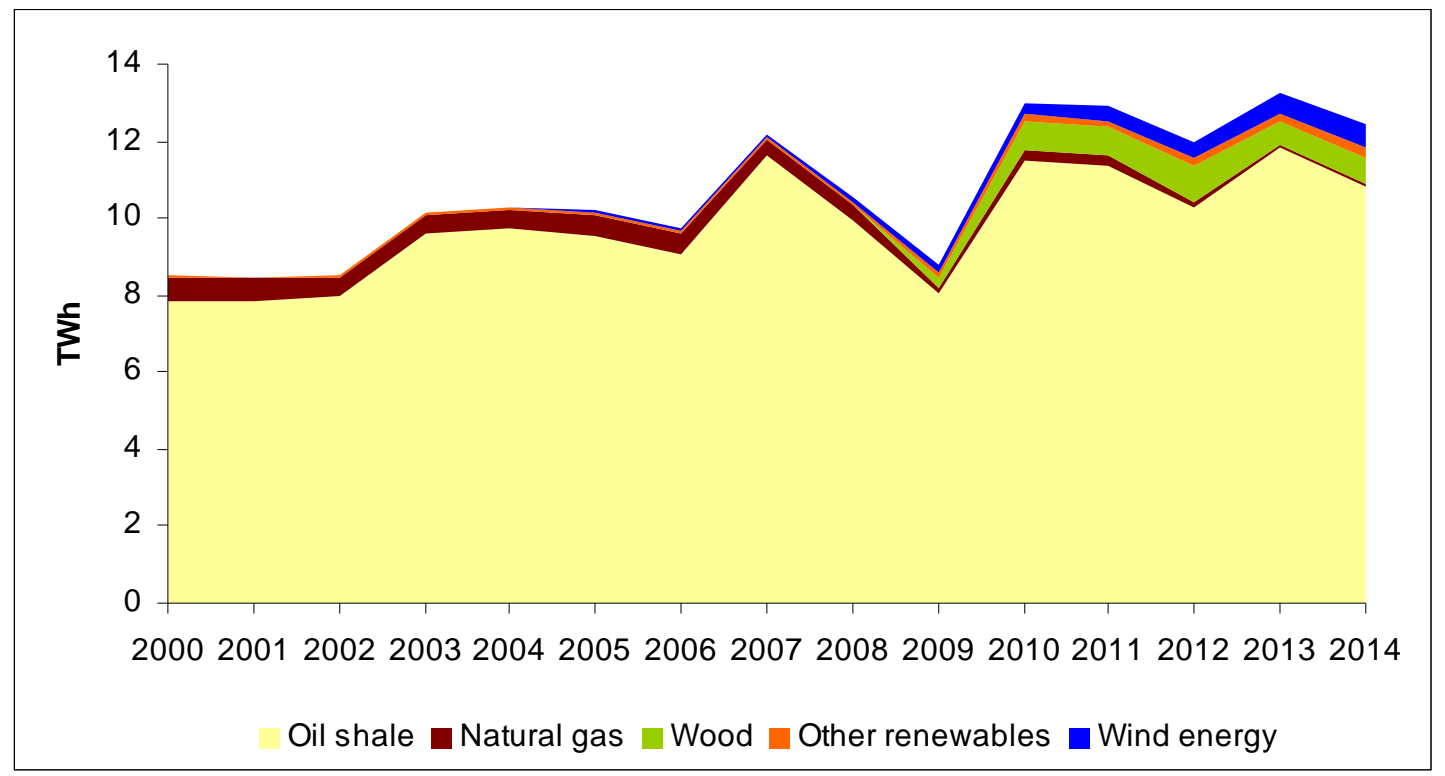

Figure 1. The share of oil shale in Estonia's electricity production. Source: Statistics Estonia.

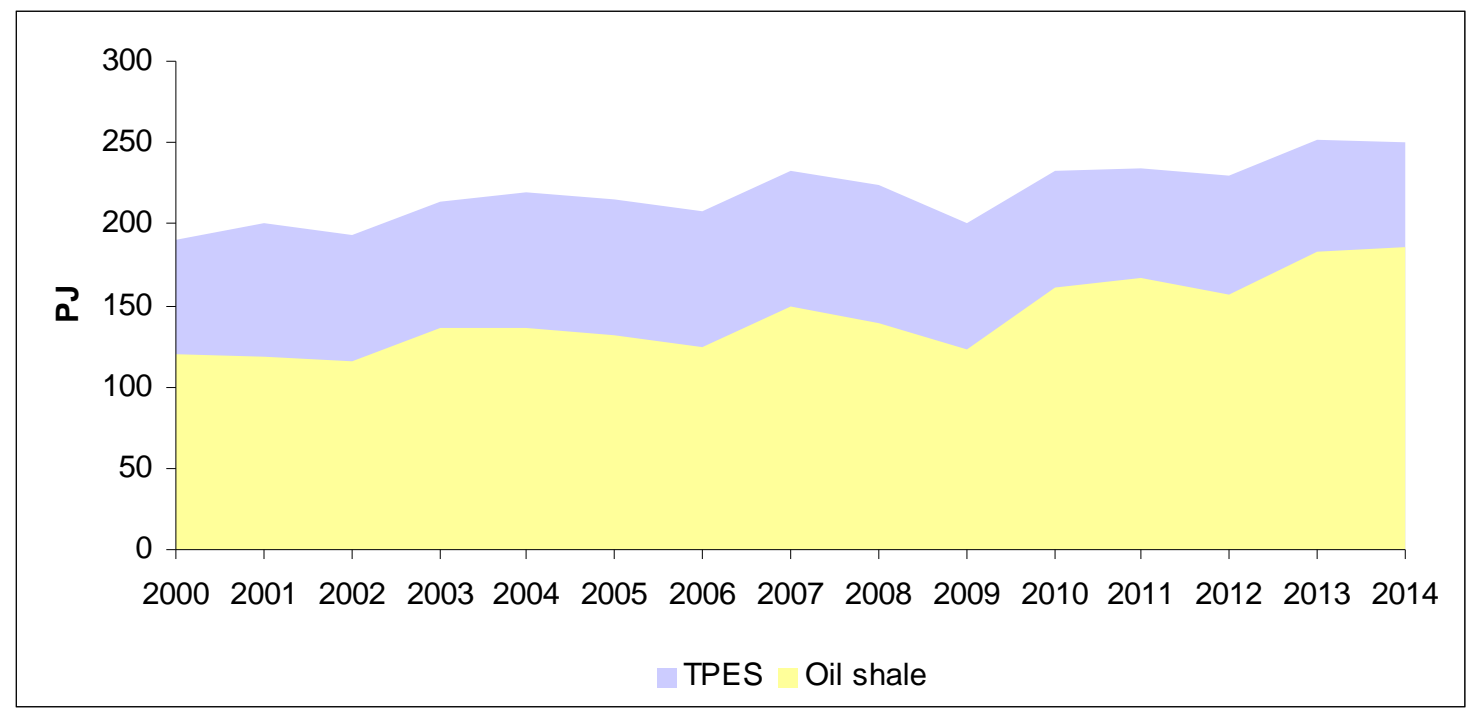

Figure 2. The share of oil shale in Estonia's total primary energy supply (TPES). Source: Statistics Estonia.

This state-regulated and extremely carbon-intensive sector has shown remarkable resistance to liberalisation, unbundling and privatisation; the three neoliberal modes of energy governance that underpin the policies of the EU, the OECD, and international donor agencies. ${ }^{26}$ In 1998, during the EU accession negotiations, the government attributed oil shale a 'special status' and backed a 
monopoly in shale-based power generation. ${ }^{27}$ The majority of electricity has since been supplied by a company called Eesti Energia, the only post-Soviet industrial complex that remains fully under state control despite repeated attempts to sell part of its shares to foreign investors. The vertically integrated enterprise incorporates both oil shale mining and major capacities for power generation and distribution, including all shale-fired thermal plants (Figure 3), several wind farms, and the majority of network utilities. Only a few independent enterprises have recently become involved in the distribution business, while transmission networks were separated in 2010 and moved under another state-owned company, called Elering, which now acts as the transmission system operator (TSO). Even post 2013, when Estonia became one of the last EU states to open its power market fully for competition, following a three-year delay that was granted to ensure 'security of supply', Eesti Energia is still expected to retain a de facto monopoly in the local market due to the lack of both competition and infrastructural connections within the Baltic Sea region. ${ }^{28}$

What one might want to call a 'nationalist' framing of the energy sector is thus strikingly at odds with the neoliberal framing of economic reform that the government has otherwise adopted, apparently without reservations. ${ }^{29}$ In contrast to Estonia's poster-child image in market liberalisation, the local political elite tends to regard the oil shale industry as an extension of government that helps guarantee energy security, at least in power production, which is expected to take priority over any calculations of profitability. The prevailing discourse of energy security enshrined in a series of planning documents compels the state to supply its citizens and businesses with affordable electricity produced within its territorial borders, thereby remaining immune to external forces of political and technical leverage. The core principle underpinning state energy policy to date is hence 'sovereignty', meaning that energy security is "scaled to the nation, derives from prevailing geopolitical relations, and centres on physical cross-border flows". ${ }^{30}$ Unlike other Baltic states, Estonia has proscribed all commercial trade of electricity with Russia despite having excellent infrastructural connections, and has endeavoured to cover all consumption with domestic sources, with only a fraction of its total energy needs to be met with Russian gas imports (less than 10 per cent). ${ }^{31}$ Sovereign energy policy is thus premised on self-sufficiency, which until very recently has been realised through exclusive state regulation.

Given the centrality of oil shale to this discourse, it would be misleading to essentialise the resource as a geologically given substance that happens to be conveniently located at Estonia's north-eastern margins bordered by the Narva River. Rather, oil shale should be accounted for as a nationally-defined resource or patrimony that has come into existence through particular historical-geographical circumstances and thus retained in relation to calculations of risks associated with Russian supplies. Indeed, the period following the restoration of Estonia's statehood has seen extensive efforts to reposition the fossil fuel as the 'wealth of the nation'; inherited through its territory and embedded in the labouring bodies and specialist knowledge of its population. ${ }^{32}$ The key objective of the reindependent state is to continue shale-based electricity production in order to maintain not just uninterrupted supply, but also a "unique" techno-scientific complex. ${ }^{33}$ Having staged the resource as a patrimony, the state will not acquiesce to exterior demands of market competition and environmental law. On the 
contrary, the industry appears to be flying firmly in the face of EU climate and energy frameworks, since the government has succeeded in placing national security interests amidst ongoing efforts of market construction, even if this is to be achieved at the expense of environmental sustainability and 'security of supply' more narrowly conceived. ${ }^{34}$

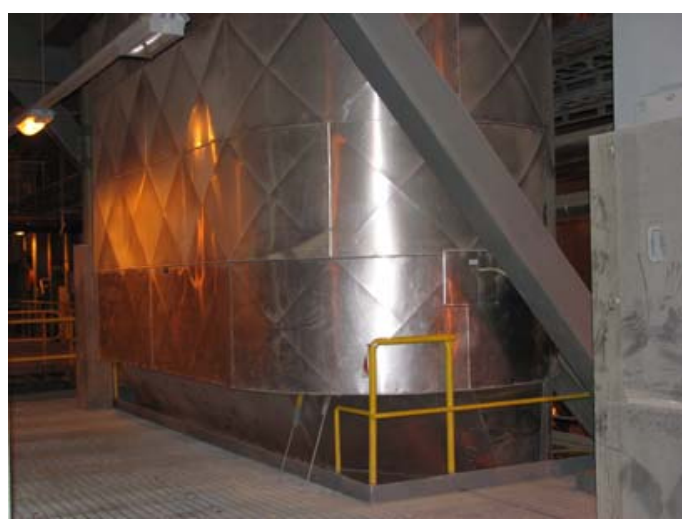

a

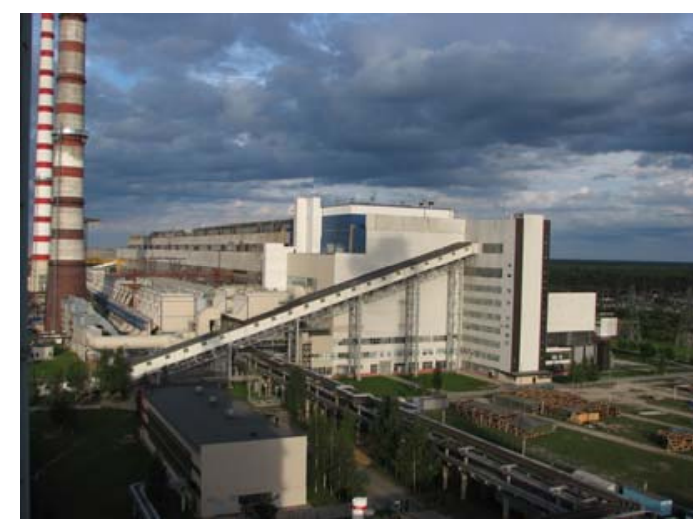

b

Figure 3. The direct burning of oil shale in furnaces (a) located in the 'Eesti' power station (b), which along with the nearby 'Balti' station forms Narva Power Plants, a subsidiary of Eesti Energia. Photos by author.

Yet, this seemingly consensual policy conceals a series of inconvenient paradoxes. While the industry is regarded as not just a "backbone to our energy system" but a "backbone to our independence", as asserted by former Minister of Economic Affairs who solely represents the owner of Eesti Energia, it was in fact built up by the occupying Soviet regime with little consultation. ${ }^{35}$ Although smallscale mining was launched as early as in 1916 and acquired major significance for the nation-building exercises of the first Estonian government before World War II, shale would never have reached its current status without the large-scale industrialisation, non-ethnic immigration and ecological devastation carried out under the aegis of Soviet authorities. In fact, production was expanded to achieve its economies of scale with the sole purpose to deliver electricity and household gas to the north-western parts of the USSR, before a nuclear power plant was commissioned in St Petersburg in the late 1970s. The consequence of this peculiar infrastructural history is that the Baltic electricity system is able to function only as a part of the Soviet-era network, being synchronised with the transmission grids of north-west Russia and Belarus (part of the IPS/UPS). At the same time, the industry continues to be single-handedly responsible for the vast majority of Estonia's emissions, water use, waste disposal and landscape destruction, ensuing decades of intense exploitation under lax environmental measures. ${ }^{36}$ Although the highly polluting and energy inefficient process of burning such low-calorific material was contested by local scientists as far back as the 1960s, to this date there have been neither clear incentives nor opportunities to reform the sector. ${ }^{37}$

As Estonia celebrates the centenary of the industry in 2016, oil shale exploitation continues to be upheld in direct opposition to the former imperialist regime, notwithstanding the fact that its feasibility is bound up with the technoeconomic legacies of the same regime. Mocking the desire for isolation, a local 
journalist has suggested that the ultimate "touchstone for Estonian nationalism should be to forsake the electricity enabled by the occupiers". ${ }^{38}$ As my interviews and document analysis further revealed, this paradox pervades recent debates over the industry's compatibility with the EU environmental and competition law. In anticipation of profound reforms, 'patrimony' has come to be viewed in highly contradictory terms - at once a critical source of economic growth, employment and state dividends and a heavily subsidised sector; a showcase of Estonia's unique technological expertise in utilising unconventional resources and a relic of backward Soviet industrialism; a warranty of socio-political stability in an industrial district populated mainly by Russian-speaking workers and a potential factor of instability confronting mainstream transnational policies.

It is not just the association of patrimony and security that is laden with contradictions and adjusted over time. These adjustments also penetrate the very essence and attributes of oil shale as the patrimony or its resource ontologies; defined as "assumptions about what resource substances are, their affordances, and what sustains them", along with the techno-scientific networks through which the geophysical is rendered intelligible, appraised and circulated as an energy commodity. ${ }^{39}$ Whereas proponents of continued exploitation emphasise that oil shale offers a sense of security against present threats, others recall Estonia's constitutional duty to preserve the 'wealth of the nation' for future generations an acute demand given the inevitable decline in resource quality that follows from a century of extraction. This dilemma reopens the ontological politics through which the resource has historically been made and its potentialities enacted. Notably, the government policy has until recently conceived of the resource as a solid mineral ore that needs to be utilised for domestic electricity supply via direct burning in power plants (Figure 3). As a solid fuel, it serves as a substitute for coal rather than an 'unconventional' hydrocarbon. With changing legislation and market situation, however, the industry has begun to look into other ways of utilising the patrimony, specifically by processing the mineral into liquid fuels.

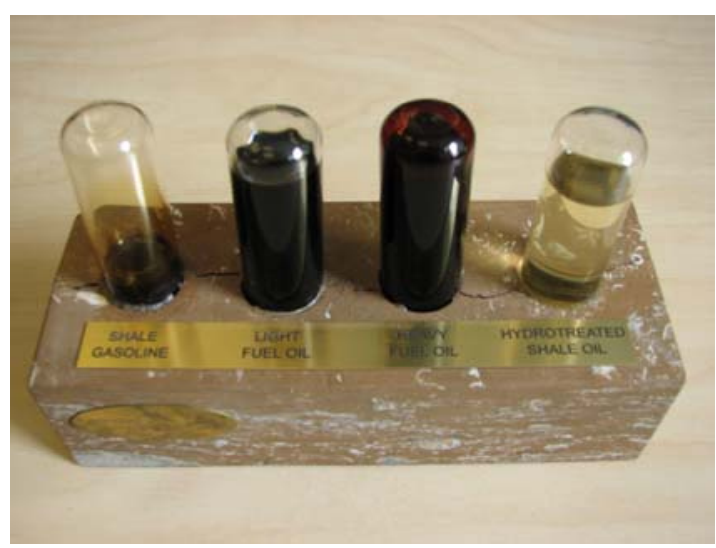

a

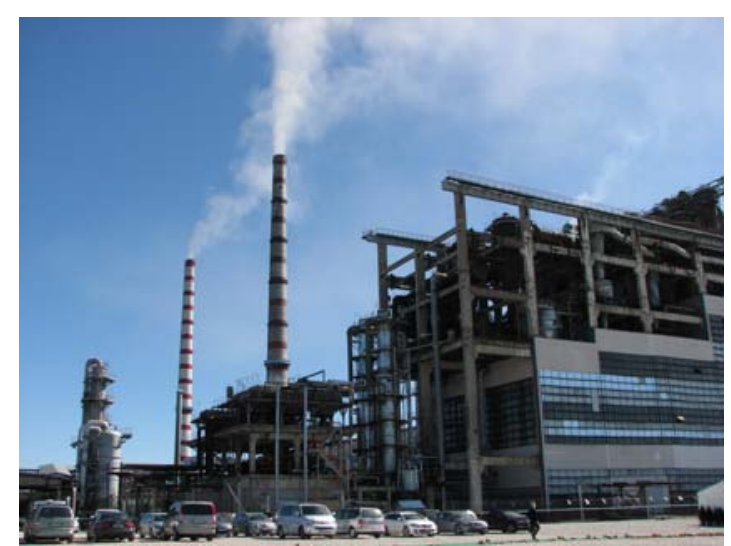

b

Figure 4. Samples of different fractions of shale oil (a) produced in Eesti Energia's oil plant (b). Photos by author.

As a key alternative to the 'shale-to-power' mode of resource-making, shale oil is far from a novel invention. Experiments with converting organic-rich rocks into viscous bitumen-like substances upon heating in airtight retorts have been 
undertaken in many parts of the world. In Estonia, the resulting heavy oil fractions supplied low-octane transport fuel before World War Two and were later used continuously in the chemical industry and as shipping fuel (Figure 4). Yet, recent demands for deregulation and decarbonisation are seen to create a new impulse for the 'shale-to-liquids' business, which so far has remained largely outside state supervision, although maintained by both Eesti Energia and two private companies. ${ }^{40}$ The industry now anticipates that more of the feedstock will be converted into shale oil, and potentially into synthetic crude, leaving carbon to be released by end-consumers. ${ }^{41}$ Perhaps unsurprisingly, domestic oil production is claimed to back up energy security similarly to shale-based electricity. Whether enacted as a solid or liquid fuel then, the patrimony-security nexus implies that shale continues to be positioned as the linchpin of sovereign energy policy. Indeed, very few local actors would dare to say that the remaining deposits are insignificant for the country's future or a 'non-resource' that should be left untouched in the ground.

In brief, the indigenous fossil fuel is taken to underlie the very possibilities of national self-determination. Since its matter-energy has been part and parcel of Estonia's economy and statehood 'from the outset', ${ }^{42}$ local actors keep exploring different ways to define and exploit the resource without being able to revoke its significance. It is this unsettled (onto)political space that the EU imperative of 'energy transition' have encountered, disclosing not just alternative institutional and infrastructural framings of the sector, ${ }^{43}$ but also diverging conceptions of oil shale and what it means for security. The following sections first document ongoing struggles over expert authority in devising both 'energy security' and state-market relations in governing the sector, before discussing how this has led to contending enactments of the resource itself.

\section{Between market and non-market: disrupted transitions}

When Estonia started accession negotiations in 1995 and the implications of EU requirements became clear, the fate of the postsocialist industry was highly uncertain, because neither the course of the open market nor the technical solutions required for fulfilling the various acquis communautaire were known in advance. In the course of exploring future options, the shale-centred convictions have gradually begun to soften across the local energy elites, including government officials, academic experts, industry managers and others in charge of energy policy-making. These elites have since issued a series of calculations that invariably prescribe that shale's share in the energy mix will be lowered significantly, either by imported gas or nuclear power. ${ }^{44}$ For some, the EU requirements further entail a need to transition from the state-run carbonintensive economy to a market-led system progressively based on renewables, as explained below. Yet, in spite of growing external pressures, various exercises in scenario-building, and public and less public disputes, the situation remains de facto largely unchanged. Following oil shale's 'special status' attribution and subsequent derogations from the EU law, energy transition has turned out to be a much less linear and fatal process than anticipated. Instead of passively adhering to external authorities, as recent scholarship on postsocialist transformations concedes, new member states have succeeded in influencing both the design of EU policies and their translation into practice. ${ }^{45}$ What is less noted, however, is that 
the vision of transition may simultaneously open up novel possibilities for the establishment of national expertise in shaping state-market relations in energy governance.

As noted earlier, the coordination of EU energy policy increasingly revolves around the problem of 'energy security'. If the concept means different things to differently situated actors, the definition mobilised by Brussels envisages a knowledge-based lower carbon economy, which is predicated on a regionally integrated, albeit internally reterritorialised market. In line with neoliberal tenets, its core measures include deregulation, infrastructural integration and diversification of supply, along with increased use of renewables, energy efficiency and technological innovation. ${ }^{46}$ Although the use of domestic resources is regarded as complementing this vision, particularly for heating and electricity, this clearly contradicts the sovereignty-based discourse prevailing in Estonia, according to which the government remains responsible for providing the nation with affordable services, best secured through exclusive state control and maximum use of oil shale. This has justified the concentration of key functions to Eesti Energia along with only partial unbundling, even though the mechanism of electricity pricing was eventually delegated to market forces.

The persistence of the sovereignty-based discourse indicates that electricity remains ambiguously conceived as both a strategic public good and as an exchangeable good that is traded like any other market commodity. ${ }^{47}$ The success of the Estonian government in navigating these definitions therefore affirms Mitchell's proposition that the smooth functioning of the free market always conceals a range of non-market practices and institutions on which its existence depends. ${ }^{48}$ Instead of finding a clear-cut, territorially and temporally marked distinction between socialist and capitalist regimes of energy provision, or even a "transitional region occupying some intermediate space," 49 one can conclude that it is precisely the protectionist mode that has played a key role in enabling a market economy to be realised in Estonia.

The government's recurrent flirtations with privatisation further demonstrate how energy security arguments blur the distinction between market and non-market practices in state policy, for conservative and liberal parties alike. Despite two serious attempts to induce private investment capital for replacing the Soviet-era thermal units commissioned over 40 years ago, the energy monopoly remains fully owned by the state. The first was the attempted sale of half of Narva Power Plants, Eesti Energia's subsidiary, to NRG Energy, a US-registered company; an agreement from which the government abruptly pulled out in 2002 following six years of negotiations. According to the detailed analysis of Kuus, the "unprecedented elite and popular protest campaign" that emerged against the 'NRG' deal foremost tied issues of security to state sovereignty, as fears of higher electricity prices and loss of economic independence were pitted against wider political strategies of aligning the US interests against the reputed threat of Russian imperialist manoeuvres. ${ }^{50}$ Likewise, during the second attempt at privatisation, involving the initial public offering (IPO) of a quarter of Eesti Energia's shares on the London stock exchange in May 2010, the intertwined accounts of security and sovereignty prevailed in pro- and contra-privatisation arguments alike, whereas both agendas were grounded on the need to continue using domestic oil shale instead of importing Russian power. Again, the 
government vetoed the deal at the last minute and decided instead to gradually inject fresh capital in the company via state bonds. ${ }^{51}$ The company's aspirations for a world-class business, more recently involving expansion of its operations into shale oil development in the USA and Jordan, have thereby come into conflict with growing, yet divided concerns over the loss of state control, stability and reputation. ${ }^{52}$

What is at issue here is not so much the traditional 'state versus market' dilemma, since both the 'NRG' and 'IPO' events suggest that privatisation may be considered to equally enhance and undermine energy security. Rather, it is the central role of oil shale as the material basis for security and the geo-logics that sustain it as an energy resource. Whether explicitly addressed or not, the fossil fuel continues to be enacted primarily in its solid form and mobilised as the hidden force that guarantees supply, competitiveness, jobs, budget balance and broader socio-political stability. As such, it is also expedient for fighting against "the omnipresent Russian threat to the Estonian statehood". ${ }^{53}$

The implications of resource ontologies become clearer when 'energy transition' is regarded as commensurate with 'low-carbon transition' and environmental measures more generally. Here, the resistance to institutional and regulatory reform is compounded by the specific properties of the raw material processed, including its high carbon, sulphur and ash content. Over recent years, various prerequisites of this double transition - particularly the constraints imposed by the Landfill Directive, the Industrial Emissions Directive (IED), the internal energy market packages and, most seriously, the EU climate and energy frameworks with their '20-20-20' objectives, changing rules of carbon trading and the 2030 and 2050 roadmaps - have all run up against the materiality of the resource that arises from the 'shale-to-power' enactment, necessitating major investments and innovation. Most urgently, Estonia was to be forced to close down all of its power units based on pulverised combustion by 2016 due to the IED Directive (2010/75/EU). These units account for up to 66 per cent of total generation capacity, with only two recently built units permitted to stay in operation. ${ }^{54}$ Even if some older units could be renovated, it was feared that they would still turn out uncompetitive due to the industry's commitment to buy all of its carbon allowances from 2013 onwards instead of continuing to receive them for free. ${ }^{55}$

In the context of prevailing uncertainty, the industry's prospects have thus become subject to a particular socio-technical controversy, ${ }^{56}$ at the centre of which lie various options for replacing existing generation capacity with alternative sources of supply. For this, the state planning documents currently in force outline different combinations of oil shale, combined-heat-and-power, nuclear power, imported natural gas, and renewables. Yet, none of the proposed scenarios have officially been adopted. 57 Moreover, despite gradually heading towards diversification, the core principle remains that all electricity - and ideally also the resources for feedstock - should originate within the borders of the state, whereas exports are acceptable only after domestic needs are met. Curiously, these scenarios regard oil shale as central to security, even after complete marketisation, by covering up to 70 per cent of supply. At the same time, it is also anticipated that the open market will bring in new possibilities, so that no single pathway to a less carbon-intensive economy is deemed conceivable. The planning documents thus 
concede that the state is unable to exert its policy preferences on the deregulated sector without subsidising the construction of new shale-fired power stations. This revelation again blurs the boundaries between market and non-market practices, without signalling any imminent decline in oil shale exploitation.

Instead of delineating a lower carbon future, this controversy over resourcemaking has opened up a space for inventive action in which the EU requirements are both implemented in unforeseen ways and themselves redesigned in response to established resource materialities. The most striking example here is the harnessing of shale-fired power stations for meeting one of the '20-20-20' targets: to cover 20 per cent of gross energy consumption with renewables (25 per cent for Estonia). Having missed earlier milestones, Estonia rapidly raised the share of renewables and became the first state to reach its target in $2011 .{ }^{58}$ Besides extended wind parks, the key secret behind this achievement is the practice of adding timber and other biomass to the process of oil shale combustion. Disputed as an inefficient use of bio-energy, which not only deprives smaller businesses from market share and subsidies ${ }^{59}$ but also distorts the local timber market, the practice has sparked furious protest amongst Eesti Energia's competitors, consumer associations, the forestry industry, the political opposition, and leading energy experts. Amidst heated controversy, the details of the national law have been repeatedly adjusted to either enable or disable co-combustion, while Eesti Energia suspended the practice in late-2012, only to resume it in 2016. Whatever the ultimate solution will be, this case illustrates that different regulatory regimes can be inventively arranged to co-exist within the same socio-material assemblage, without major innovation or demarcation between low- and high-carbon pathways.

Meanwhile, the distinctive socio-technical position and materiality of oil shale has also enabled a careful adjustment of EU law. Following negotiations over the IED Directive, Eesti Energia was allowed to maintain four older shale-fired power units equipped with de-SOx installations and, moreover, permitted to also use the rest with limited working hours until 2023. Only two units out of twelve, accounting for 12 per cent of total capacity, have since been decommissioned. This decision builds on an earlier derogation from the Landfill Directive that allowed Estonia to continue dumping the highly alkaline ashes of shale combustion combined with water only until 2009,60 but was eventually removed from the Accession Treaty altogether after Eesti Energia failed to find alternatives to its ash transport technique and reduce the amounts of liquid waste disposed. Likewise, the post-2013 carbon trading rules have been adapted to Estonia's alleged needs, enabling the industry to request continued free allocation of allowances. ${ }^{61}$

In effect, these repeated derogations render the national energy economy even more grounded in oil shale. Since there is no technical capacity for large-scale imports to the 'Baltic energy island', except from Russia, the resource continues to be securitised and depoliticised as the only viable option Estonia currently has. At the same time, as the sense of urgency has now been lifted (and as there was no binding scenario anyway), local companies proceed with investments into diverging supply options based on both domestic production and imports, even though there is enough capacity until 2023 to secure continued supply, provided that older units are maintained. ${ }^{62}$ Having blocked the IPO, the government has agreed to support Eesti Energia in constructing a new power plant to the same extent as was expected from investors. Yet, as tightening climate policy has 
prompted local specialists to question whether the remaining low-calorific resources should be all wired into electricity, the industry simultaneously bets on increased shale oil production and exports, supposed to yield fewer emissions and higher profits. In parallel, the TSO advocates improved connections to the European grid, along with gas-fired stations for balancing peak load. The private sector, meanwhile, is busy extending various wind and solar parks in fierce competition with the monopoly for state subsidies. Both state planning and reallife developments therefore concede uncertainty over oil shale's long-term availability and economic feasibility, yet nonetheless affirm its continued importance.

More broadly, these derogations support the observation of Kuus that security programmes have not been single-handedly authored by Western politicians and intellectuals and imprinted upon candidate states. ${ }^{63}$ Rather, the former have equally relied on vernacular notions of security and a handful of gatekeepers familiar with local problems. Indeed, the formation of expert knowledge in this case has turned out to be a 'two-way' process, as Kuus suggests, where local actors strategically deploy Western concepts, such as 'security of supply', while transforming their content and meaning. In spite of their small size, countries such as Estonia have not merely deferred to neoliberal policies, but instead have developed a proactive policy regime that installs state-specific security conceptions amidst ongoing negotiations over the design of the market and its relations with third countries. ${ }^{64}$ However, an equally important, yet less explored question is how such 'national' expertise is formed and subsequently mobilised at the expense of alternative sources of knowledge. Whilst Kuus emphasises the role of a small circle of 'elites' in silencing dissenting views, this paper now turns to investigate whether this concealment is always achieved.

\section{The reconfiguration of expertise}

Despite the onset of marketisation, Estonia's energy policy continues to be premised on state ownership and self-sufficiency in isolation from extra-territorial supplies. Far from being ruled out by EU regulations, oil shale enjoys a monolithic status in the energy mix, having effectively been securitised, depoliticised and rendered into a matter of expert decision-making. Yet, if we consider energy expertise, like any form of expertise, as a distributed social process that requires continuous investment, 65 then established credentials may no longer hold when their relevance and validity is cast into doubt. As documented in the remainder of this paper, the industry has recently become the object of a form of repoliticisation, particularly in association with the gradual extension of market logics into a state-governed domain, but also due to more longstanding disagreements and internal fragmentation within the domain of elite knowledges that inform the performance of energy security. Furthermore, this controversy has overflown into the ontological politics of the fossil fuel resource and associated infrastructures that underscore security claims.

Traditionally, very few people in Estonia have had the opportunity to familiarise themselves with a matter that requires highly specialist knowledge and access to restricted information. Conducted in secluded circles, energy policy is considered within the remit of techno-scientific expertise, the preserve of qualified engineers and geo-scientists working either in the Tallinn University of 
Technology and the Academy of Sciences or directly for the industry, or indeed both. It is the task of these technical experts to define what supply options are acceptable to pursue under the banner of security and what options shall be rejected as irrelevant, incompetent or unconceivable. The supremacy of technical expertise is further grounded in long-standing aspirations for a national industrial science and the 'scientification of oil shale' that took place in tandem with the large-scale electrification and industrialisation programmes of the Soviet era, as several university departments were established with the sole purpose of supporting the industry. ${ }^{66}$ Indeed, the industry originates in the augmentation of both infrastructure and knowledge. It is perhaps not so surprising then that the 'resourceness' of oil shale appears provident, entangled as it is with established techno-economic networks that are deemed objectively given and have hitherto deserved little public discussion.

Are alternative enactments of energy resources, therefore, even possible? Intriguingly, the limits to technocratic energy governance are being exposed by the rise of another form of expertise, a new generation of managerially educated experts. While oil shale science has long suffered from a generational gap in educating new specialists and lack of funding, leading to a closure of its two main research institutes around the time of EU accession, ${ }^{67}$ the reforms implied by Brussels have revealed fundamental disagreements between eminent academics. This lack of consensus has proven a serious disadvantage for the academics' relations with other energy elites, particularly with the state company, which is now led by younger men with degrees in economics and business administration. For Eesti Energia's management, technically sound options need to be first tested under business logics and metrics, as they seek to re-identify themselves as an "international energy company" rather than a "local electric monopoly" tasked to care for the population. ${ }^{68}$ In doing so, the managers have begun to adjust established security conventions to new business opportunities, sometimes borrowing from market-based vocabularies and other times ignoring them entirely. What appears to be a broader trend in post-Soviet industrial complexes, the 'engineers vs. managers' conflict has reached a stage where technocrats have become largely removed from decision-making and both state and industry funding for oil shale research has diminished. 69

In turn, the government seems to place more trust in the in-house expertise of Eesti Energia, especially during the critical times leading to 'market opening' in 2013. To the dismay of both technical experts and competing enterprises I interviewed, the state monopoly has taken over key functions in energy policymaking, including calculations for state planning and drafting regulations that were previously outsourced to the academics. As several leading officials oscillate their careers between Eesti Energia and the Ministry of Economic Affairs, the boundaries between the industry and its owner appear increasingly blurred, with the state company being accused of acting like the state itself, exemplified in the pun "Eesti energia=Eesti Energia" (trans. Estonian energy [policy] equals Eesti Energia). Even if the state-industry allies themselves no longer know where the sector will be heading in the open market, they have successfully imposed a "monopoly of truth" on the subject, as some of their most outspoken critics lament.70 
Meanwhile, any attempts to bring energy issues subject to more open debate have either been short-lived or, worse still, transformed into mere publicity tools for elite politics. For example, in 2008, ministry officials responsible for the revision of state plans in light of the EU '20-20-20' requirements convened a series of Energy Forums, which besides contributions from technocrats also requested the input of the industry's opponents and lay experts. But instead of providing a template for more democratic forms of energy governance, the fora turned farcical when the brand was later occupied by Eesti Energia and converted into their regular media gatherings on the eve of 'market opening'. Other non-parliamentary initiatives have similarly descended from public view, including various analyses and workshops organised by civil society activists, artists and film-makers. While public debates surface every now and then - some arguably orchestrated by the state-industry allies, others less so - none has had far-reaching effects. The real-life governance of the sector, meanwhile, is certainly beginning to adjust to changing market realities, but simultaneously maintains the "conservative and even regressive" approach that has arguably dominated Estonia's energy policy for nearly two decades. ${ }^{71}$

Yet, despite being effectively contained, the Energy Forums and other events still have important ramifications. Indeed, they disclose the fragmentation of established expert authority on security issues, the incalculable state of uncertainty following from market liberalisation and, most importantly, diverging definitions of strategic energy resources and infrastructures. Rather than leaving the space of politics intact, these disclosures may well indicate initial changes in established forms and sites of energy governance and associated resource ontologies. For example, the fora were preceded by a Green Party campaign that succeeded in their brief entry into Parliament between 2007-2011. As a result of this campaign energy issues have since been routinely addressed in all party programmes. ${ }^{72}$ Moreover, the formerly taken-for-granted domain is also increasingly interrogated by the media. A recent transfer of Eesti Energia's ownership from the Minister of Economic Affairs to the Minister of Finance (and from conservatives to liberal democrats) in April 2014 opens up another important opportunity to renegotiate power between the government and industry.

Most significantly, the improving position of managerial expertise has simultaneously made it possible for the ranks of energy elites to be supplemented with new professionals, whose experience is more diverse and often gained abroad. Notably, the event of unbundling in 2010 did not just deliver transparency and equal access to market participants; it also, crucially, created an alternative body of competency that has quickly begun to dismantle the 'monopoly of truth'. The rate at which Elering, the TSO, has seized both counter-expertise and infrastructural responsibilities is remarkable. In a race with Eesti Energia, the most popular employer in Estonia alongside Skype, the TSO now hires a number of younger specialists, many of them educated in foreign universities (and several female). Their annual reports on 'security of supply' offer a primary source of alternative logics of resource-making, which in themselves are not novel but for the first time are backed up with thorough calculations, carefully designed scenarios, and references to international research. Driven by a strong belief in the panacea of the market to resolve energy security problems once sufficient physical infrastructure 
is in place, the TSO has begun to disintegrate the patrimony-security nexus by working towards improved grid connections, diversification of supply sources and fair competition, including in natural gas supply. Moreover, since publishing their first report Elering's leaders have quickly moved to challenge the narrative of selfsufficiency. In their view, energy security is no longer state-based but a regional issue, since its cornerstone is integration with European networks rather than maintaining independent capacity. Oil shale, the CEO explains, is still "an important part of the picture, but should not be the starting point for weighing other solutions". ${ }^{73}$

These efforts are being met with growing enthusiasm in other bureaucratic circles. A recent report of the National Audit Office likewise laments the fact that the government still regards security as solely grounded in oil shale, lacks any vision of the sector's future beyond the year 2023, and withdraws from options that would lead to less carbon-intensive production. ${ }^{74}$ Another nascent actor, the Estonian Renewable Energy Association, whose leader has international degrees and work experience from Brussels, has gone a step further and launched a campaign for a ' 100 per cent renewables' future, besides coordinating dissent among alternative energy producers. 75 Other dissenting 'managers' have contributed to policy-making or even been elected to the Parliament. Many of these new opinion-leaders no longer strictly qualify as 'experts' specialising in a particular field, but rather as what Stengers calls 'diplomats'; namely high-profile figures whose efforts are dedicated to bringing energy resources as a matter of collective concern subject to more broad-based debates. ${ }^{76}$

The increasing frequency of dissenting analyses and the fierce opposition with which these are being met by Eesti Energia therefore point towards a possible shift in the prevailing security discourse and associated resource ontologies. This is further manifested in changing investment priorities. Notably, the government has begun to call for eventual disconnection from Russian electricity networks and has managed to inscribe this objective into the current EU energy security and Energy Union agendas. Likewise, the TSO is in negotiations with its Baltic colleagues to desynchronise their grids from the IPS/UPS system by 2025. Other indications concern ongoing quarrels with Finland over the location of an EUfunded LNG terminal and potential investments into new nuclear units in either Lithuania or Finland with a further aim to weaken competing projects, specifically in Kaliningrad. ${ }^{77}$

Two reservations, however, need stating. The first is that this sociotechnological controversy cannot be projected as a mere confrontation between state- and market-led modes of energy governance. Certainly, it is possible to identify a few dichotomous views based on either continued self-sufficiency or complete neoliberalisation. Yet, the majority of arguments are located at a continuum, where different aspects of energy security become progressively decoupled from national sovereignty, albeit in uneven and conflicting ways. For example, integration with Western networks is not so much considered an alternative to investments in oil shale power plants, but rather an independent element that supplements existing strengths. Likewise, shale-based electricity cannot be fully replaced by shale oil production, not least due to the fact that existing power and oil plants are technically dependent on each other. Furthermore, there is an emerging possibility of discarding the established view of 
security as independent from external supplies altogether. If "Russia is no longer an omnipresent threat"78 in light of the EU-Russia energy dialogue and plans for a unified electricity market, ${ }^{79}$ then strong connectedness to their Eastern neighbour may against all odds turn out the key guarantor of 'security of supply' for the Baltic states. Indeed, the local elites have more recently begun to reposition the industry as a strategic transit corridor linking the two markets, yet simultaneously continue to argue for a need to desynchronise the grids. ${ }^{80}$ Instead of adhering to single solutions, the everyday conduct of energy politics navigates various currents that transcend state-level policy-making.

Another reservation is that despite their multiplying effects on the politics of knowledge, energy security debates cannot be easily sustained outside existing spaces of expertise. Whether conducted by technical or managerial experts, they stand for a predominantly elite field where non-specialists and lay people have little say. It is just that the sources of authority have proliferated, following clashes between those who acclaim expertise and their changing convictions. Even if the emergence of alternative knowledge claims, resource definitions and sites of politics affirms that "energy security is not and should not be a matter primarily regulated by national governments", 81 it does not take place outside the domain of techno-bureaucratic expertise as such. Rather than evidencing a 'redistribution of expertise' to lay publics, as recent STS-informed work on knowledge polities observes, ${ }^{82}$ possible energy futures are here made through an ongoing reconfiguration of expertise, without necessarily limiting their political potential.

\section{Geo-logics and geo-politics: concluding remarks}

The previous sections have documented how national energy politics may be mediated by a single geological resource no matter what policy measures are forged. Oil shale becomes politically productive precisely because it continues to be securitised and de-politicised through deterministic accounts of the resource and its place in the regional energy system. But although this kind of 'geo-politics' has proven impervious to the imperatives of energy sector deregulation and decarbonisation, I suggest that the very possibility of 'transition' has simultaneously disrupted and proliferated an already divided space of expertise in performing energy security. With the demise of technocratic expertise and selective adoption of neoliberal tenets by managerial elites, the sovereignty-based discourse has become subject to growing contestation and reinvention, even if it still serves as an ideal for state policy. One conclusion of this study is therefore that the choice between high-carbon and low-carbon pathways is not so much foreclosed by supranational authorities than made through the reconfiguration of national expertise, during which the binary between market and non-market modes of energy governance is vigorously tested and reinvented.

By way of broader conclusion, however, I want to shed further light onto the argument that such reconfigurations of expertise may render open not just alternative registers of energy security, but more substantial onto-political questions of the essence, meaning and viability of the geological resource that pivots security claims. While 'competing resource ontologies' have previously been defined as imprints of foregone processes of resource-making that remain prone to dispute, ${ }^{83}$ the case of oil shale further reveals that the resource itself can assume multiple material forms of existence as a result of its complex socio-technological 
histories and contested futures. Indeed, a central question in the Estonian controversy is for what purposes the remainder of rapidly degrading deposits should be used, and for how long should they last. Should they be considered a solid mineral resource used in power generation or as a future 'unconventional' hydrocarbon akin to shale gas - or, conversely, as a relic of the past that will eventually be rendered a 'non-resource' by the merciless logics of the market?

Further, the multiplying effects of the ontological politics of resource-making are not limited to oil shale's alternate states of material potentiality, or its 'shaleto-power' and 'shale-to-liquids' enactments, but intersect with wider geo-logics. In the context of mounting regulatory constraints domestically and growing interests in alternative fossil fuels elsewhere, the Estonian industry increasingly seeks to capitalise upon its accrued technical expertise, along with exporting a significant share of their production output. Viewed in this context, oil shale is elevated from a nation-specific security instrument to a more-or-less standard commodity traded in the global marketplace. The fossil fuel is still staged as a patrimony, but one with an improving price and export potential that must not be overlooked. ${ }^{84}$ In a remarkable twist then, the market argument helps to depoliticise the resource in a manner similar to security considerations, albeit with the difference that uncertainty is no longer resisted, but rendered into a normal state of affairs, where all resource enactments seem feasible and business opportunities are up for grabs. In 2010 and 2011, Eesti Energia's ambitions to become an "undisputed world leader" in oil shale exploitation ${ }^{85}$ were rewarded with two concessions far abroad, respectively in Jordan and Utah, US, rendering the state-owned business a part of global capital and resource speculation. The contingent marketisation of oil shale thus bears important ramifications for the development of other unconventional deposits, since Estonia comes to represent a successful case in maintaining the industry despite being subject to the most stringent regulations.

In all these cases, however, it is yet to be decided what the 'unconventional' is; a marginal feedstock limited to the local market, a nascent hydrocarbon commodity or a mere promise that will never be realised. Indeed, we cannot be certain whether oil shale is a resource of the future or a resource of the past. A more productive approach would be to approach the onto-political making of unconventional fossil fuels as comprising not just 'retentions' of their complex histories but also 'anticipations' of their possible futures, which in conjunction yield distinct geological entities subject to continued collective experimentation. ${ }^{86}$ In Europe, such 'anticipatory resources' clearly interfere with the construction of the regional geo-energy space, rather than providing the tacit and inert background of neorealist accounts, yet may themselves become transfigured as a result. It is perhaps not too ambitious to conclude then that the success or failure of unconventional energy development amounts to a geographically contingent process, which cannot be subsumed by the linear logics of energy transition unless a new consensus between shifting security conventions and contending resource ontologies is reached. 


\section{Acknowledgements}

I am grateful to the many industry specialists and policy experts who shared their time and expertise with me in Estonia, Brussels, London, Jordan and the USA in 2010-2012. The manuscript has also benefited from detailed feedback by Andrew Barry, Joe Gerlach, Merje Kuus, Tomas Maltby, Gisa Weszkalnys, and three anonymous reviewers. I hope their invaluable suggestions will open up future conversations even if I have failed to incorporate them fully.

\section{Notes}

${ }^{1}$ S. Bouzarovski 'East-Central Europe's changing energy landscapes: a place for geography', Area 41/4 (2009) pp.452-63.

${ }^{2}$ C. Dupont and S. Oberthür (eds.) Decarbonization in the European Union: Internal Policies and External Strategies (Basingstoke: Palgrave Macmillan 2015).

${ }^{3}$ Elering 'Eesti elektrisüsteemi varustuskindluse aruanne' [Report on the security of supply in Estonia's electricity system] (Tallinn: Elering 2012); J. Francu, B. Harvie, B. Laenen, A. Siirde \& M. Veiderma 'A study on the EU oil shale industry - viewed in the light of the Estonian experience' (Brussels: European Academies Science Advisory Council 2007).

${ }^{4}$ A. Mäe 'Estonian energy strategy and its implications to the regional cooperation' in A. Sprūds \& T. Rostoks (eds.) Energy: Pulling the Baltic Region Together or Apart? (Riga: Latvian Institute of International Affairs 2009) pp.250-81; M. Maigre 'Energy security concerns of the Baltic States (Tallinn: International Centre for Defence Studies 2010).

${ }^{5}$ T. Maltby 'European Union energy policy integration: A case of European Commission policy entrepreneurship and increasing supranationalism', Energy Policy 55 (Apr. 2013) pp.435-44; K. Kama 'On the borders of the market: EU emissions trading, energy security, and the technopolitics of "carbon leakage", Geoforum 51 (Jan. 2014) pp.202-12.

${ }^{6}$ European Commission 'Communication from the Commission to the European Parliament and the Council: European Energy Security Strategy' (Brussels 2014).

${ }^{7}$ L. Reins 'In Search of the Legal Basis for Environmental and Energy Regulation at the EU Level: The Case of Unconventional Gas Extraction', Review of European, Comparative \& International Environmental Law 23/1 (2014) pp.125-33.

${ }^{8}$ S. Jiusto 'Energy Transformations and Geographic Research', in N. Castree et al. (eds.) $\underline{A}$ Companion to Environmental Geography (Chichester: Wiley-Blackwell 2009) pp.533-51; G. Bridge, M. Bradshaw, S. Bouzarovski \& N. Eyre 'Geographies of energy transition: space, place and the lowcarbon economy', Energy Policy 53 (Febr. 2013) pp.331-40. For Eastern Europe, see also S. Bouzarovski 'Post-socialist energy reforms in critical perspective: Entangled boundaries, scales and trajectories of change', European Urban and Regional Studies 17/2 (2010) pp.167-82.

${ }^{9}$ T. Richardson \& G. Weszkalnys 'Resource Materialities', Anthropological Quarterly 87/1 (2014) pp.5-30.

${ }^{10} \mathrm{G}$. Bridge 'Energy (in)security: world-making in an age of scarcity', The Geographical Journal 181/4 (2015) pp.328-39; P. Le Billon 'Resources', in K. Dodds, M. Kuus \& J.P. Sharp (eds.) The Ashgate Research Companion to Critical Geopolitics (Farnham: Ashgate 2013), pp. 281-303.

${ }^{11}$ A. Barry Material Politics: Disputes along the Pipeline (Chichester: Wiley-Blackwell 2013); J. Dittmer 'Geopolitical assemblages and complexity', Progress in Human Geography 38/3 (2014) pp.385-401; V. Squire 'Reshaping critical geopolitics? The materialist challenge', Review of International Studies, 41/1 (2015) pp.139-59.

${ }^{12}$ See also G. Bridge 'Resource geographies II: the resource-state nexus', Progress in Human Geography 38/1 (2013) pp.1-13; E.E. Ferry \& M.E. Limbert (eds.) Timely Assets: The Politics of 
Resources and Their Temporalities (School for Advanced Research Press 2008); Richardson \& Weszkalnys (note 9).

${ }^{13}$ F. Ciută 'Conceptual notes on energy security: total or banal security?', Security Dialogue $41 / 2$ (2010) pp.123-44; R. Dannreuther 'Energy security and shifting modes of governance', International Politics 52/4 (2015) pp.466-83; B.K. Sovacool \& I. Mukherjee 'Conceptualizing and measuring energy security: A synthesized approach', Energy 36/8 (2011) pp.5343-55. See also Bridge (note 10).

${ }^{14}$ This is the oft-quoted formulation from J. Bielecki 'Energy security: is the wolf at the door?', The Quarterly Review of Economics and Finance 42/2 (2002) pp.235-50.

${ }^{15}$ Bridge (note 10$)$.

${ }^{16}$ M. Kuus Geopolitics Reframed: Security and Identity in Europe's Eastern Enlargement (New York: Palgrave Macmillan 2007).

${ }^{17}$ Le Billon (note 10), p.282.

${ }_{18} \mathrm{Cf}$. A. Mol 'Ontological politics. A word and some questions', in J. Law and J. Hassard (eds.) Actor Network Theory and After (Oxford: Blackwell 1999) pp.74-89. See also J. Law After Method: Mess in Social Science Research (London: Routledge 2004); S. Hinchliffe Geographies of Nature: Societies, Environments, Ecologies (London: Sage 2007).

${ }^{19}$ E.g. S. Dalby 'The geopolitics of climate change', Political Geography 37 (2013) pp.38-47; N. Clark 'Geopolitics at the threshold', Political Geography 37 (2013) pp.48-50; D. Depledge 'Geopolitical material: Assemblages of geopower and the constitution of the geopolitical stage', Political Geography 45 (2015) pp.91-2. This approach commends the recent reinstallation of the 'geo' at the heart of critical geography and social theory more broadly.

${ }^{20}$ B. Braun 'Buried Epistemologies: The Politics of Nature in (Post)colonial British Columbia', Annals of the Association of American Geographers 87/1 (1997) pp.3-31; S. Elden 'Secure the volume: Vertical geopolitics and the depth of power', Political Geography 34 (May 2013) pp.35-51.

${ }^{21}$ Kuus (note 16), p.55. See also E. Berg \& S. Oras 'Writing post-Soviet Estonia on to the world map', Political Geography 19/5 (2000) pp.601-25; P. Aalto Constructing Post-Soviet Geopolitics in Estonia (London: Frank Cass 2003); and other publications by these authors.

${ }^{22}$ A. Mañé-Estrada 'European energy security: Towards the creation of the geo-energy space', Energy Policy 34/18 (2006) pp.3773-86.

${ }^{23}$ For a detailed analysis of the methdology, see K. Kama Unconventional Futures: Anticipation, Materiality, and the Market in Oil Shale Development, D.Phil. thesis in School of Geography and the Environment (University of Oxford 2013).

${ }^{24}$ Statistics Estonia Statistical Yearbook of Estonia (Tallinn 2015).

25 Ibid.

${ }^{26}$ E.g. R.W. Bacon \& J. Besant-Jones 'Global electric power reform, privatization, and liberalization of the electric power industry in developing countries', Annual Review of Energy and the Environment 26 (Nov. 2001) pp.331-59.

${ }^{27}$ A. Hamburg 'Energy situation and its development in reindependent Estonia', in Baltic-Finnish Conference. Energetics: From Research to Innovation (Tallinn: Finnish Academies of Technology 2001) pp.53-7.

${ }^{28}$ E.g. Estonian Competition Authority Estonian Electricity and Gas Market Report 2012 (Tallinn: Konkurentsiamet 2013); European Comission's report on Estonia, https://ec.europa.eu/energy/sites/ener/files/documents/2014 countryreports estonia.pdf, accessed 4 July 2016. The situation was somewhat alleviated with the launch of the Estlink2 cable between Finland and Estonia in 2014.

${ }^{29}$ H. Hannula, S. Radoševic \& G.N. von Tunzelmann Estonia, the New EU Economy: Building a Baltic Miracle? (Aldershot: Ashgate 2006); J. Gillies, J. Leimann \& R. Peterson 'Making a successful 
transition from a command to a market economy: the lessons from Estonia', Corporate Governance: An International Review 10/3 (2002) pp.175-86.

30 Bridge (note 10) p.5.

${ }^{31}$ This represents the lowest level of dependency in Eastern Europe, see M. Bradshaw Global Energy Dilemmas: Energy Security, Globalization, Climate Change (Cambridge: Polity 2012) p.102.

${ }^{32}$ Cf. E.E. Ferry Not Ours Alone: Patrimony, Value, and Collectivity in Contemporary Mexico (New York: Columbia University Press 2005); T. Perreault \& G. Valdivia 'Hydrocarbons, popular protest and national imaginaries: Ecuador and Bolivia in comparative context', Geoforum 41/5 (2010) pp.689-99.

${ }^{33}$ S. Liive 'Oil shale energetics in Estonia', Oil Shale 24/1 (2007) pp.1-4.

${ }^{34}$ Compare this, for example, with analyses of Estonia's situation by the EU authorities; e.g. European Commission 'Member States' Energy Dependence: An Indicator-Based Assessment' (Brussels: European Union 2013).

35 J. Parts 'Importance of future oil shale industry plans for Estonia', keynote at the International Oil Shale Symposium (Tallinn 2009).

36 E.g. NAO-Estonia 'Alternatives for electricity production' (Tallinn: National Audit Office of Estonia 2012); A. Raukas \& J.M. Punning 'Environmental problems in the Estonian oil shale industry', Energy \& Environmental Science 2/7 (2009) pp.723-8.

${ }^{37}$ An excellent analysis of the industry's history is R. Holmberg Survival of the Unfit: Path Dependence and the Estonian Oil Shale Industry (Linköping: Linköping University, Department of Technology and Social Change 2008).

${ }^{38}$ My translation from A. Hvostov 'Eesti haigus' [Estonian disease] Eesti Ekspress (8 Febr. 2013).

${ }^{39}$ Richardson \& Weszkalnys (note 9), p.19.

${ }^{40}$ VKG Oil and Kiviõli Keemiatööstus. All three companies are currently commissioning new oil factories.

${ }^{41}$ The technical and economic feasibility of syncrude production is yet to be proven outside laboratory conditions.

${ }^{42}$ Cf. B. Braun 'Environmental issues: inventive life', Progress in Human Geography 32/5 (2008) pp.667-79.

43 Bouzarovski (note 8).

${ }^{44}$ E.g. A. Laur \& K. Tenno 'Sustainable development of the Estonian energy sector: A modelling approach', in Ü. Ennuste \& L. Wilder (eds.) Harmonisation with the Western Economics: Estonian Economic Developments and Related Conceptual and Methodological Frameworks (Tallinn: Estonian Institute of Economics 1999) pp.283-302; T. Tammeoja \& E. Reinsalu 'Forecast of Estonian oil shale usage for power generation' Oil Shale 25/2 (2008) pp.115-24. See also Francu et al. (note 3).

45 For Estonia specifically, see e.g. M. Crandall 'Soft Security Threats and Small States: the Case of Estonia' Defence Studies 14/1 (2014) pp.30-55; M. Kuus '"Those goody-goody Estonians": toward rethinking security in the European Union candidate states', Environment and Planning D 22 (2004) pp.191-207; M. Lehti 'Estonia and Latvia: A "new" Europe challenges the "old"?' in D.J. Smith (ed.) The Baltic States and Their Region: New Europe or Old? (Amsterdam: Rodopi 2005) pp.87114.

${ }^{46}$ See EU Energy Security Strategy 2014, the '2020', '2030' and '2050' energy frameworks and Directive 2005/89/EC.

${ }^{47}$ Bielecki (note 14); K. Westphal 'Energy policy between multilateral governance and geopolitics: whither Europe?' International Politik und Gesellschaft 7 (2006) pp.44-62. 
${ }^{48}$ T. Mitchell 'The properties of markets', in D.A. MacKenzie, F. Muniesa \& L. Siu (eds.) Do Economists Make Markets? (Princeton, N.J.: PUT 2007) pp.244-75.

${ }^{49}$ Ibid, p.246.

${ }^{50}$ M. Kuus 'Sovereignty for security?: the discourse of sovereignty in Estonia' Political Geography 21/3 (2002) pp.393-412.

${ }^{51}$ E.g. S. Vedler \& T. Vahter 'Kuidas Ansip hoidis ära Eesti suurima erastamise' [How Ansip turned down the largest privatization in Estonia] Eesti Ekspress (20 May 2010).

52 See also Kama (note 23), Ch.8.

${ }^{53}$ Kuus (note 50), p.409.

${ }^{54}$ Elering (note 3), Francu et al. (note 3).

55 Mäe (note 4), Maigre (note 4).

${ }^{56}$ M. Callon, P. Lascoumes \& Y. Barthe Acting in an Uncertain World: An Essay on Technical Democracy (Cambridge, Mass: MIT Press 2009).

57 'Energiamajanduse arengukava aastani 2020' [Development plan for the energy economy until 2020] and 'Elektrimajanduse arengukava aastani 2018' ['Development plan for the electricity economy until 2018]. These plans were under revision at the time this article was written.

58 Eurostat database 'Share of renewable energy in gross final energy consumption'.

${ }^{59}$ In consequence, Eesti Energia has turned out to be the main beneficiary of subsidies for renewable energy since they were introduced in 2007, having received a third of the national support for the co-combustion of biomass and shale. See NAO-Estonia (note 36).

${ }^{60}$ Francu et al. (note 3); Mäe 2010 (note 4).

${ }^{61}$ Kama (note 5).

${ }^{62}$ Elering (note 3); NAO-Estonia (note 36).

${ }^{63}$ Kuus (notes 16, 50).

${ }^{64}$ This ambition has been explicitly expressed by Estonian officials, see e.g. E. Kisel 'Developing Estonian energy policy hand in hand with EU energy packages', in Yearbook 2008/2009 (Tallinn: Estonian Ministry of Foreign Affairs 2009).

${ }^{65}$ H.M. Collins \& R. Evans Rethinking Expertise (Chicago: UCP 2007).

${ }^{66}$ Holmberg (note 37).

${ }^{67} \mathrm{~J}$. Meriküll et al. 'Power without manpower: Forecasting labour demand for Estonian energy sector', Energy Policy 49 (2012) pp.740-50; V. Oja, 'Is it time to improve the status of oil shale science?' Oil Shale 24/2 (2007) pp.97-9.

68 S. Diel 'A Company bigger than the Nation Itself' (Tallinn: ERR News 2012), http://news.err.ee/Economy/954325b3-8d36-4c7a-957c-2e5a1e1b7bb9, accessed 4 July 2016.

${ }^{69} \mathrm{Cf}$. S.A. Wengle 'Engineers versus managers: experts, market-making and state-building in Putin's Russia', Economy and Society 41/3 (2012) pp.435-67.

${ }^{70} \mathrm{~K}$. Kallas 'Miks on elekter tegelikult kallis' [Why is electricity actually expensive?] http://kajakallas.ee/2010/10/07/miks-on-elekter-tegelikult-kallis/ (2010), accessed 4 July 2016. This expression was reiterated by many of my interviewees.

${ }^{71}$ Hamburg (note 27).

72 A. Sikk \& R.H. Andersen 'Without a tinge of red: The fall and rise of Estonian Greens', Journal of Baltic Studies 40/3 (2009) pp.349-73.

${ }^{73}$ My translation from T. Veskimägi 'EL energiapoliitika pärast Durbani kliimakonverentsi' [EU energy policy after Durban climate conference] http://www.taaviveskimagi.ee/2011/12/elenergiapoliitika-parast-durbani-kliimakonverents/ (2011), accessed 4 July 2016. 
${ }^{74}$ NAO-Estonia (note 36).

${ }^{75}$ See http://www.taastuvenergeetika.ee/wpcontent/uploads/2012/10/Estonia RE100 summary-eng.pdf, accessed 4 July 2016.

${ }^{76}$ I. Stengers 'The Cosmopolitical Proposal', in B. Latour \& P. Weibel (eds.) Making Things Public: Atmospheres of Democracy (Cambridge, Mass.: MIT Press 2005), pp.994-1003.

${ }^{77}$ See e.g. A. Grigas The Politics of Energy and Memory between the Baltic States and Russia (Farnham: Ashgate 2012).

${ }^{78}$ Lehti (note 45) p.98.

${ }^{79}$ E.g. P. Aalto (ed.) The EU-Russian Energy Dialogue: Europe's Future Energy Security (Ashgate: Aldershot 2008).

${ }^{80}$ A. Reimer 'Venemaa pürgib Eesti energiajulgeoleku tagajaks' [Russia aspires to become the guarantor of Estonia's energy security] Eesti Päevaleht (23 Jan. 2013).

81 Bouzarovski (note 8), p.179.

${ }^{82} \mathrm{~S}$. Whatmore \& C. Landström 'Flood apprentices: an exercise in making things public', Economy and Society 40/4 (2011) pp.582-610; S. Hinchliffe, L. Levidow \& S. Oreszczyn 'Engaging cooperative research', Environment \& Planning A, 46 (2014) pp.2080-94.

${ }^{83}$ Richardson \& Weszkalnys (note 9).

${ }^{84}$ Note that this research did not cover more recent developments that follow from the fall in global oil prices, which had immediate effects on the profitability of shale oil production.

${ }^{85}$ Eesti Energia Creating New Energy! Annual Report 2010-2011.

${ }^{86} \mathrm{Cf}$. A. Barry 'The politics of contingency: Events, travelling models, and situations', Paper presented at the RGS-IBG Annual International Conference (2014); G. Weszkalnys 'Anticipating oil: the temporal politics of a disaster yet to come', Sociological Review, 62 (2014) pp.211-35. 